\title{
'The Belfast Chameleon': Ulster, Ceylon and the Imperial Life of Sir James Emerson Tennent
}

\author{
Jonathan Jeffrey Wright ${ }^{1}$
}

Late in 1844, The Economist carried a pithy report, reflecting on one of the more curious episodes in the life of the Belfast-born writer, parliamentarian and colonial administrator James Emerson Tennent - his capture, and subsequent donation to the Belfast Natural History and Philosophical Society (BNHPS), of a live chameleon.

The Belfast papers state that Mr. Tennent, M.P., has sent over to their Natural History Society a Cameleon [sic], which he caught on Mount Calvary, and that it is still alive in the Museum. Strange how it should occur to the Honourable Member to present such a reptile to his constituents, as a memorial of their connection with him! ${ }^{2}$

Brief as it, this report intrigues on a number of levels. For the biographer, the pointed reference to the fact that it was 'such a reptile' as a chameleon that Emerson Tennent had presented to his constituents is telling, highlighting the fact that he was a viewed, in some quarters, as changeable and untrustworthy. More broadly, the report foregrounds the globally connected nature of the

1 Jonathan Jeffrey Wright is a postdoctoral research fellow on the Scientific Metropolis Project at Queen's University Belfast. The research on which this paper is based was funded by the Irish Research Council (formerly the Irish Research Council for the Humanities and Social Sciences) and by the Arts and Humanities Research Council. The support of both bodies is gratefully acknowledged.

2 The Economist, ii (1844), p. 1498. 
BNHPS, raising questions about the collecting activities of its members: was Emerson Tennent unique, or were others transporting specimens back to Belfast from the exotic locations to which their careers took them? But above all, the report illustrates Belfast's interconnectedness with the wider British world, for here we read The Economist, a London publication, reprinting a story from a Belfast paper, which relates to the activities of an Ulsterman in the Middle East - not formally a part of the British Empire, but a region increasingly subject to British influence. ${ }^{3}$ In short, The Economist's report does rather more than announce the donation of a chameleon to the BNHPS: it raises the issue of Belfast's connections, both cultural and political, with the broader British world. In exploring the imperial life of Sir James Emerson Tennent, this essay will seek to shed further light on these connections.

\section{Beyond the 'bad question'}

To begin, some preliminary reflections on the existing scholarship on Ireland and empire are necessary. Until recently, work in this area has tended to focus on what Stephen Howe has termed the 'bad question' - was Ireland a colony? ${ }^{4}$ Complicated by the fact that Ireland can appear both as a colony or as an integral part of the British state, and the Irish as both victims and participants, subjugates and oppressors, this question is as confused as it is enduring. 'For the Irish', Alvin Jackson has observed, 'the Empire ... provided both the path to social advancement and the shackles of incarceration. ${ }^{5}$ Given this duality, it proves unhelpful to fixate solely on Ireland's status within the empire. Rather than opening debate, the question as to whether or not Ireland itself was a colony tends to close it down: encouraging an all-or-nothing mentality, in which Ireland must be either wholly colonial, or wholly non-colonial, it falsely assumes, as Kevin Kenny has noted, that there is an 'ideal' colonial state against which the Irish experience can be 'judged as either adequate or deficient'. ${ }^{6}$ Such an

3 Tellingly, Emerson Tennent was tasked, during his travels in the region, with discussing British interests with the Egyptian ruler, Muhammad Ali. The Times, 5 Nov. 1844.

4 Stephen Howe, 'Questioning the (bad) question: "was Ireland a colony?", Irish Historical Studies, xxxvi (2008), pp. 138-52. For one set of responses to this question see the essays gathered in Terrence McDonough (ed.), Was Ireland a colony? Economics, politics, and culture in nineteenth-century Ireland (Dublin, 2005).

5 Alvin Jackson, 'Ireland, the union, and the empire, 1800-1960', in Kevin Kenny (ed.), Ireland and the British Empire (Oxford, 2004), pp. 123-53 at p. 123.

6 Kevin Kenny, 'Ireland and the British Empire: an introduction' and Joe Cleary, 'Postcolonial Ireland', in Kenny (ed.), Ireland and the British Empire, pp. 1-25 at p.2 (for quote) and pp.251-88 at p. 253. 
assumption reflects neither the complexity of Irish attitudes towards the British Empire, nor the considerable diversity of that empire. An incrementally acquired and inconsistently administered assortment of ports, protectorates, mandates and colonies (crown, settlement and administrative), the British Empire was far from monolithic, and Ireland's place within it - colonial in some respects, non-colonial in others - need not necessarily be viewed as exceptional. ${ }^{7}$

Increasingly attuned to this complexity, a newly emerging body of scholarship, typified by Barry Crosbie's recent study of Irish networks in nineteenth-century India, has begun the process of exploring the Irish experience of (and contribution to) empire in more imaginative ways. ${ }^{8}$ Yet, while we are learning increasingly more about Irish doctors and missionaries active in the empire, and about those individuals who forged links with Indian nationalists in order to challenge imperial power, much work remains to be done. Relatively little is known, for example, about the careers and experiences of those Irishmen involved, more formally, in the government and administration of the empire. ${ }^{9}$ That many were involved is clear. Leaving aside the more obvious examples, men such as George Macartney, whose varied career as a diplomat and colonial governor took him, during the second half of the eighteenth century, to Russia, Grenada, India, China and the Cape of Good Hope, or Frederick Temple Blackwood, the marquess of Dufferin and Ava, who served as viceroy in both Canada (1872-78) and India (1884-88), it is possible to identify numerous Irishmen active, during the course of the eighteenth and nineteenth centuries, in the administration of the British Empire. ${ }^{10}$ One might point to such figures as Sir Robert Cowan, governor of Bombay, 1729-34; Arthur Dobbs, governor of North Carolina, 1754-65; Somerset Lowry Corry, the second Earl Belmore, governor of Jamaica, 1828-32; William Porter, attorney general of the Cape

7 Piers Brendon, The decline and fall of the British Empire, 1781-1997 (New York, 2008), pp. 98-99; Cleary, 'Postcolonial Ireland', p. 253.

8 Barry Crosbie, Irish imperial networks: migration, social communication and exchange in nineteenth-century India (Cambridge, 2012). See also, Jennifer Regan-Lefebvre, Cosmopolitan Nationalism in the Victorian Empire: Ireland, India and the politics of Alfred Webb (Basingstoke, 2009) and Michael Silvestri, Ireland and India: nationalism, empire and memory (Basingstoke, 2009).

9 Patrick O'Leary, Servants of the empire: the Irish in Punjab, 1881-1921 (Manchester, 2011), is a notable exception.

10 For Macartney, see Thomas Bartlett (ed.), Macartney in Ireland, 1768-72: a calendar of the chief secretaryship papers of Sir George Macartney (Belfast, 1979), pp. vii-xlviii and Peter Roebuck (ed.), Macartney of Lisanoure, 1737-1806: essays in biography (Belfast, 1983). Dufferin awaits the attentions of a modern biographer, but see Sir Alfred Lyall, P. C., The life of the marquis of Dufferin and Ava (2 vols, London, 1905) and, for a more impressionistic account of his life, Harold Nicolson, Helen's Tower (London, 1937). 
Colony, 1839-73; or Robert Hart, who rose from the position of student interpreter in the Chinese consular service to shape the Chinese Imperial Maritime Customs service, becoming, by the late nineteenth century, the most influential European in China. ${ }^{11}$

Aside from the fact that all may be identified as Irishmen, the aforementioned can all, more particularly, be identified as Ulstermen: Macartney and Dobbs hailed from Co. Antrim, and Porter and Cowan from Co. Londonderry; Hart was born in Portadown, Co. Armagh; Dufferin's estate was located in Clandeboye, Co. Down; and Belmore's family owned substantial tracts of land in counties Fermanagh and Tyrone. This point is worth highlighting insofar as it directs attention to another largely overlooked area in Irish imperial history: that of the Ulster contribution to, and experience of, empire. That the empire was important in Ulster in the late-nineteenth and early-twentieth centuries is readily apparent. Reflecting on his imperially impoverished childhood in 1950s Birmingham, David Cannadine has noted that he did not 'come from an imperial city in ways that would have been true had I been born and brought up in Glasgow or Belfast or Liverpool or London-great, outward-looking, maritime communities, with their shipyards and warehouses, their docks and harbours and beckoning horizons, which were still in the 1950s closely linked to the old imperial realms across and beyond the seas. ${ }^{12}$ The cynic might cavil at the description of 1950s Belfast as 'outward-looking', but the broader point rings true: Belfast, with its ship-building and manufacturing, was a workshop of the empire. Added to this, the empire is known to have formed an important, if complicated, component of the Ulster Unionist mindset, a point neatly illustrated by the rhetoric of the Solemn League and Covenant. Signed by over 218,000 Ulstermen on 28 September 1912 ('Ulster Day'), the Covenant expressed opposition to Home Rule and commitment to the 'unity of the Empire', albeit in a way that challenged the authority of the imperial parliament. ${ }^{13}$ Yet, while it is well known that, during the era of Home Rule, empire provided unionists with what Alvin Jackson has characterised as 'spiritual comfort', little is known about the character-or, indeed, existence-of Ulster Unionist imperial

11 J. L. McCracken, New light at the Cape of Good Hope: William Porter, the father of Cape Liberalism (Belfast, 1993); H. C. G. Matthew and Brian Harrison (eds), Oxford dictionary of national biography (60 vols, Oxford, 2004), xiii, p. 752; xvi, pp. 340-42; xxv, pp. 590-93 (henceforth ODNB); James McGuire and James Quinn (eds), Dictionary of Irish biography from the earliest times to the year 2002 (9 vols, Cambridge, 2009), ii, pp. 872; iii, pp. 340-42; iv, pp. 495-96.

12 David Cannadine, Ornamentalism: how the British saw their empire (London, 2001), pp. 182-83.

13 A. T. Q. Stewart, The Ulster crisis: resistance to Home Rule, 1912-14 (London, 1967), pp. 58-68 (p.62 for the text of the Covenant). 
sentiment in the pre-Home Rule period. ${ }^{14}$ Nor, moreover, has any sustained attempt been made, following the insights of the 'new imperial history', to explore the empire as it was experienced 'at home' in Ulster, or to trace the ways in which people 'lived' and 'thought' imperially at times when the empire was not, for political reasons, 'a subject of popular critical consciousness', but was simply an everyday fact of life. ${ }^{15}$

These are, in general terms, the lacunae towards which the following discussion will speak. Leaving the 'bad question' to one side, it will seek to shed light on the mid-nineteenth-century Ulster experience of empire by reflecting on the career of James Emerson Tennent, an early exponent of constructive unionism, and a sometime colonial administrator, whose career encompassed Belfast, London and Ceylon. In so doing, it will first contextualise Emerson Tennent's imperial experience by offering an overview of his life and career. Following this, it will trace the development of his thought regarding the empire and his utilisation of imperial rhetoric, before turning to examine his experience of imperial service in Ceylon. Finally, it will broaden out to reflect upon the ways in which he brought the empire home, enabling others to experience it through him.

\section{An imperial life?}

While Emerson Tennent is primarily of interest because he served as colonial secretary in Ceylon between 1845 and 1850, focusing solely on this period of his life would be to suggest a disjointed biography, and a career pursued in discrete colonial and metropolitan contexts. Both biographically unsatisfactory and historically inaccurate, such an approach would obscure as much as it reveals, for as the work of scholars such as Catherine Hall and Alan Lester has demonstrated, Britain's colonies were not places apart. ${ }^{16}$ The metropolitan centre and its colonial peripheries were interconnected in myriad ways, and imperial lives were lived in a variety of contexts, not all of them colonial. If Emerson Tennent's

14 Alvin Jackson, 'Irish unionists and the empire, 1880-1920: classes and masses', in Keith Jeffery (ed.), An Irish empire? Aspects of Ireland and the British Empire (Manchester, 1996), pp. $123-48$ at p. 145.

15 This passage draws on Catherine Hall and Sonya O. Rose, 'Introduction: being at home with the empire', in Catherine Hall and Sonya Rose (eds), At home with the empire: metropolitan culture and the imperial world (Cambridge, 2006), pp. 1-31 at pp. 2-3.

16 Catherine Hall, Civilising subjects: metropole and colony in the English imagination, 1830-1867 (Cambridge, 2002); Hall and Rose (eds), At home with the empire; Alan Lester, Imperial networks: creating identities in nineteenth-century South Africa and Britain (London, 2001). 
imperial life is to be appreciated in all its complexity it is therefore necessary to begin with a biographical overview which, following Frederick Cooper and Ann Laura Stoler, locates the colonial and metropolitan 'in a single analytic field' and offers a sense of his life as a whole. ${ }^{17}$

Who, then, was James Emerson Tennent, and what were the contexts in which he lived his life? In short, he was an ambitious provincial who travelled widely and pursued a political career in the metropolitan centre. The son of a Belfast tobacco merchant, he was an Episcopalian - both by birth and, later, inclination - and was born as James Emerson in $1804 .{ }^{18}$ As a young man he lived a somewhat peripatetic life. Having received an early education in his home town, he progressed to Trinity College Dublin but abandoned his studies and travelled east to join the Greeks in their war against the Ottoman Empire. ${ }^{19}$ Returning to Britain in the mid-1820s, he pursued a literary career in London, publishing some largely forgettable fiction and several works on Greece, while retaining a strong connection with Belfast. ${ }^{20} \mathrm{He}$ courted and married the daughter of the wealthy Belfast merchant, William Tennent (thus becoming James Emerson Tennent), and participated prominently in the agitation for parliamentary reform. When reform came, in 1832, he harboured hopes that he would be selected as one of the Belfast reformers' two candidates for election to the post-reform parliament. This was not to be. Passed over by the reformers, Emerson Tennent was, instead, approached by a faction representing Belfast's corporation and its hereditary landlord, the marquis of Donegall, and he agreed to stand as one of its candidates. Following an acrimonious contest, in which his one-time associates condemned

17 Ann Laura Stoler and Frederick Cooper, 'Between metropole and colony: rethinking a research agenda', in Frederick Cooper and Ann Laura Stoler (eds), Tensions of empire: colonial cultures in a bourgeois world (Berkeley, 1997), pp. 1-56 at p. 4.

18 Dublin University Magazine, xxxix (1852), pp. 84-97 provides an overview of Emerson Tennent's early life and career on which the following account draws. Other sources are cited where relevant.

19 James Emerson Tennent (henceforth JET) to William Emerson Tennent, 12 Oct. 1856 (PRONI, Emerson Tennent papers, D/2922/A/1/1); George Dames Burtchaell and Thomas Ulick Sadleir (eds), Alumni Dublinenses, a register of the students, graduates, professors, and provosts of Trinity College, in the University of Dublin (London, 1924), p. 264.

20 Emerson Tennent's early literary output comprised A picture of Greece in 1825 (2 vols, London, 1826); 'The last heir of Glenkerrin', in H. A. S. (ed.), Tales of all nations (London, 1827), pp. 133-45; 'Letters from the Levant', New Monthly Magazine, xx (1827), pp. 70-76, 13544, 256-67, 321-29, 434-44; xxii (1828), pp. 57-69, 104-116; xxiii (1828), pp. 313-323; Letters from the Aegean (2 vols, London, 1829); The life of a midshipman (London, 1829); 'Basilia: a tale of modern Athens', New Monthly Magazine, xxv (1829), pp. 432-444; The history of modern Greece (2 vols, London, 1830); 'An old sailor's tale', Ulster Magazine, i (1830), pp. 399-405; 'My Aunt Barbara', Ulster Magazine, ii (1831), pp. 359-67. 
him as a traitor and a turncoat, he was returned to parliament as an independent Whig in December $1832 .^{21}$

Once elected, Emerson Tennent established himself quickly in parliament, earning a reputation as a hard-working M.P. and a gifted parliamentary speaker. In particular, he distinguished himself as an eloquent defender of the British connection, representing what Angus Hawkins has recently identified as a 'progressive strand of Ulster Unionism'.22 At the same time, he repositioned himself politically, tying his fortunes to those of Edward Stanley (later, as the earl of Derby, to be Prime Minister), who he followed across the floor of the Commons, accepting the Tory whip, in $1836 .{ }^{23}$ This repositioning led some to conclude that Emerson Tennent was little more than a careerist who trimmed his sails to the prevailing political winds. The Economist's hints regarding his chameleon-like tendencies have already been noted, but others put the matter more bluntly: 'I do not imagine the political opinions of Sir Emerson [Tennent] were deeply grafted in his nature', the journalist Cyrus Redding mused, in a reminiscence penned in 1869 . 'He seemed rather to attain his personal objects by the support of his party'. ${ }^{24}$ Whether or not this was fair is debatable, but it is certainly true that his political manoeuvrings aided his career. In 1841, Robert Peel appointed Stanley as Secretary of State for the Colonies and Emerson Tennent was duly offered the secretaryship of the Board of Control for India, a position he readily accepted, anticipating that greater things would follow. ${ }^{25}$

Four years later, it appeared as though this anticipation would be fulfilled when Emerson Tennent was appointed to the position of colonial secretary of Ceylon. Appeared is, however, the operative word, for although Emerson Tennent hoped that he would, in due course, be promoted to Ceylon's governorship, his spell in the colony proved deeply disappointing. ${ }^{26}$

21 JET to Robert James Tennent, letters dated Jan. 1830 to March 1831 (PRONI, Tennent papers, D/1748/G/661/79-90); [Banner of U1ster], A brief historical sketch of parliamentary elections in Belfast: from the first general election under the reform act till 1865 (Belfast, 1865), pp. 1-7.

22 Angus Hawkins, The forgotten prime minister: the 14th earl of Derby (Oxford, 2007) p. 153. See also, John Bew, The glory of being Britons: civic unionism in nineteenth-century Belfast (Dublin, 2009), pp. 130-39.

23 Stanley to JET, 28 Nov. 1834 and Shaw to JET, 4 Jan. [-] (PRONI, Emerson Tennent papers D/2922/C/3/ 12, 23).

24 New Monthly Magazine, cxliv (1869), p. 539. $661 / 168 \mathrm{~A}-\mathrm{C})$.

25 JET to Robert James Tennent, 22 Oct. 1841 (PRONI, Tennent papers, D/1748/G/

26 Torrington to Grey, 14 Oct. 1847, in Letters on Ceylon, 1846-50: the administration of Viscount Torrington and the 'rebellion' of 1848: the private correspondence of the third Earl Grey (Secretary of State for the Colonies 1846-52) and Viscount Torrington, K. M. de Silva, ed. (Kandy, 1965) p. 56. (Henceforth Letters on Ceylon.) 
Upon arrival, he found the established civil servants - and in particular an influential group known as the 'family compact' - resentful that an outsider had been appointed as colonial secretary. Worse, with the fall of Peel in 1846, Stanley was replaced as Secretary of State for the Colonies by Earl Grey who frustrated Emerson Tennent's hopes for promotion, appointing George Byng, the sixth Viscount Torrington, as governor of Ceylon in $1847 . .^{27}$ As a Whig, Torrington viewed Emerson Tennent with suspicion and, were all this not bad enough, the colony faced rebellion as natives in the central Kandyan provinces rioted in opposition to the introduction of a range of new taxes - taxes conceived by Emerson Tennent - in the summer of 1848. The suppression of this rebellion - and in particular the imposition of martial law - proved deeply controversial, both in Ceylon itself, and in Westminster, where radicals and colonial reformers, supplied with information by disgruntled Britons resident in the colony, forced a lengthy inquiry into the events. ${ }^{28}$ To some extent anticipating the later controversy concerning Governor Edward Eyre's suppression of the Morant Bay Rebellion in Jamaica, this inquiry not only served to focus attention on the exercise of martial law, but highlighted the toxic jealousies and animosities dividing the British administration in Ceylon. ${ }^{29}$ In its fall-out, both Torrington and Emerson Tennent found themselves recalled from the colony.

Emerson Tennent's recall from Ceylon effectively marked the end of his career as a colonial administrator. Although subsequently offered the governorship of St Helena, the ill-health of his wife prevented him from taking up the position and, in December 1851, he returned to parliament as M.P. for the town of Lisburn, Co. Antrim. He was to hold this seat for less than a year, before being appointed by Disraeli as secretary to the Board of Trade, a position

27 JET to Robert James Tennent, 11 Jan. 1847 (PRONI, D/1748/G/661/212A-B); K. M. de Silva, 'Sir James Emerson Tennent: colonial administrator and historian', Journal of the Royal Asiatic Society of Sri Lanka, xli (1996), pp. 13-37 at pp. 14-16.

28 For the 1848 rebellion and its aftermath see Lennox A. Mills, Ceylon under British rule, 1795-1932: with an account of the East India company's embassies to Kandy, 1762-1795 (Oxford, 1933), pp. 168-202; Ronald P. Doig, 'Lord Torrington's government of Ceylon', Durbam University Journal, new series, xxiii (1962), pp. 49-58; K. M. de Silva, 'The "rebellion" of 1848 in Ceylon', Ceylon Journal of Historical and Social Studies, vii (1964), pp. 144-70; K. M. de Silva, 'The 1848 "rebellion" in Ceylon: the British parliamentary post-mortem; part i and part ii', Modern Ceylon Studies, v (1974), pp. 40-76, 117-37; R. W. Kostal, 'A Jurisprudence of power: martial law and the Ceylon controversy of 1848-51', Journal of Imperial and Commonwealth History, xxviii (2000), pp. 1-34.

29 Doig, 'Lord Torrington's government of Ceylon', p. 49; Kostal, 'A Jurisprudence of power', p. 27. 
he retained for the remainder of his working life. ${ }^{30}$ In course, Disraeli grew to regret this appointment. In 1867 he complained tartly that Emerson Tennent had 'turned out to be the most inefficient \& useless of our public servants ... a mere club gossip \& office lounger. ${ }^{31}$ The suggestion here is that Emerson Tennent finished his career as an indolent time-server, but this is unfair. While at the Board of Trade, he returned to literature, producing a series of works which secured him a reputation as an expert on Ceylon. In addition, he produced a treatise on the taxation of wine and a history of firearms, made numerous contributions to Notes and Queries and further developed the extensive network of political and literary connections he had first begun to cultivate during the 1830s, in particular forging a firm friendship with Charles Dickens - a friendship so close that Dickens cancelled a reading in March 1869, in order to rush to London and attend the funeral of the man he knew as 'poor dear Emerson Tennent.' ${ }^{32}$

\section{Speaking imperially}

Emerson Tennent was, then, a well-known personality, and a figure who inhabited a diverse range of contexts, political and cultural, colonial and metropolitan. Within this broader context, the first point to make when considering him as an imperial actor is that his formal career as a colonial administrator was short-lived. Having spent only five years in Ceylon, he is best viewed as someone who 'travelled through' the empire, rather than as one of the imperial careerists, identified by David Lambert and Alan Lester, who 'dwelt for extended periods in one colony before moving on to dwell in others', establishing 'meaningful connections across the empire' as they did so. ${ }^{33}$ However, as has already been noted, imperial lives could be lived in both metropolitan and colonial contexts, and it would therefore be unwise to conclude that Emerson Tennnet's time in Ceylon constituted an insignificant or digressive colonial interlude in a

30 JET to Forster, 1 March 1851 (PRONI Emerson Tennent papers, D/2922/B/14B/ 21); JET to Robert James Tennent, 21 Jan. 1851 and 23 March 1851 (PRONI, Tennent papers, D/ $1748 / \mathrm{G} / 661 / 244 \mathrm{~A}-\mathrm{B}$ and 256).

31 Quoted in Robert Blake, Disraeli (London, 1966), p. 324.

32 James Emerson Tennent, Wine, its use and taxation (London, 1855); James Emerson Tennent, The story of the guns (London, 1864); Notes and Queries, fourth series, iii (1869), p. 256; Dickens to Layard, 13 March 1869, in The letters of Charles Dickens, volume twelve 1868-1870, Graham Storey, ed. (Oxford, 2002), p. 310. Emerson Tennent's works on Ceylon will be discussed below.

33 David Lambert and Alan Lester, 'Introduction: imperial spaces, imperial subjects', in David Lambert and Alan Lester (eds), Colonial lives across the British empire: imperial careering in the long nineteenth century (Cambridge, 2006), pp. 1-31 at pp. 1-2. 
primarily metropolitan life. While his formal career as a colonial administrator lasted only five years, his engagement with empire lasted rather longer: it not only continued after his return to Britain, as he produced a series of writings which helped shape British conceptions of Ceylon, but pre-empted the time he spent in the colony. Indeed, his parliamentary rhetoric reveals him to have been thinking and speaking imperially long before his appointment to Ceylon.

Although an active parliamentarian, Emerson Tennent addressed the House of Commons infrequently, delivering only a handful of significant speeches during the course of his parliamentary career. When he did speak, however, he tended to do so at length, having first memorised a detailed script, and his speeches can therefore be read as considered statements, rather than extemporaneous polemical interventions. ${ }^{34}$ Without doubt, the most significant of these speeches was that which he delivered during the debate of Daniel O'Connell's repeal bill in April 1834. Speaking for over three hours, he simultaneously announced himself as a rising figure, cemented his working relationship with Edward Stanley and secured his reputation as an articulate spokesman of moderate unionism, articulating what John Bew has characterised as an 'expansive notion of the Union'. ${ }^{35}$ Empire was central to this 'expansive unionism', which sought to move beyond the insular, confessional concerns of Irish politics to focus on the greater glory facilitated by the British connection. Thus, during the course of the speech, Emerson Tennent repeatedly deployed the vocabulary of empire - 'empire', 'British Empire', 'imperial', 'colony', 'colonial' - and, in one particularly rousing passage, articulated his pride at being able to participate in what he viewed as the humanitarian governance of a vast empire:

Is it no accession of dignity to an Irish member of this House that he sits here to legislate, not merely for the concerns of his own little island, but for the interests of the most opulent and powerful empire in the universe ... I shall never fail to regard it as a proud distinction, that I have myself been enabled, during the course of the last twelve months, to contribute, by my own humble vote, to extend the blessings of freedom from the confines of India to the remotest shores of the Atlantic; to

34 James Grant, Random recollections of the Lords and Commons, second series (2 vols, London, 1838), ii, p. 243.

35 Stanley to JET, undated note inserted in Speech of J. Emerson Tennent, Esq. M.P. on seconding the amendment of the Right Hon. T. Spring Rice, to Mr. O'Connell's motion relative to the repeal of the union (London, 1834) (PRONI, Emerson Tennent papers D/2922/C/3/6); Bew, The glory of being Britons, p. 136. 
liberate the Hindoo, and to strike off the fetters of the African. These are triumphs beyond the reach of a "Local Legislature," these are trophies toward which the highest ambition of an Irish Parliament could never soar; these are honours which enable us, whilst we pride ourselves upon our birth-place, as Irishmen, to add to our distinctions the glory of being Britons. ${ }^{36}$

Much of this was derivative. In highlighting the 'external dignity' the Union conferred on Ireland, Emerson Tennent was drawing on Edmund Burke; indeed, he first employed the phrase within the context of a quote from Burke. ${ }^{37}$ Moreover, as Thomas Bartlett has demonstrated, the supposed benefits of the empire constituted an important dimension of the Union debates of 1799-1800, both as they were conducted in the Irish and British parliaments, and by Dublin's pamphleteers. ${ }^{38}$ Yet, if these arguments were not, in themselves, original, Emerson Tennent's re-articulation of them nevertheless reveals him to have been imperially conscious. Indeed, his assertion that he sat in parliament to legislate, 'not merely for the concerns of his own little island, but for the interests of the most opulent and powerful empire in the universe', highlights his own awareness of himself as an imperial actor, long before he set foot in Ceylon.

Further reflecting his imperial consciousness, Emerson Tennent was to employ the language of empire in parliament on a number of subsequent occasions during the course of the 1830s, but it was not until the period following his appointment as secretary to the Board of Control for India that he was to discuss imperial matters in any detail. ${ }^{39}$ Having been appointed in 1841, his tenure as secretary of the India Board coincided with the calamitous end of the First Afghan War, and between 1843 and 1845 he delivered a sequence of speeches defending British actions in the east. In March 1843, for example, he defended the widely criticised decision that Lord Ellenborough had taken to seize and repatriate the ornamental sandalwood gates believed to have been looted by the Afghans, 800 years earlier, from the temple of Somnath. The following year, he delivered a defence of Sir Charles Napier's controversial annexation of Sind,

36 Hansard's Parliamentary Debates, 3rd series, xxii (1834), pp. 1293, 1294, 1299, 1303, 1305, 1306, 1313, 1318, 1320, 1327, 1332, 1333 (empire); 1291, 1309, 1321 (British Empire); 1289, 1322 (Imperial); 1294 (colony); 1298, 1299, 1320 (colonial); 1313-14 (for quote). Henceforth cited as Hansard, with vol. no. and year.

37 Hansard, xxii (1834), p. 1296; Bew, The glory of being Britons, p. 136.

38 Thomas Bartlett, 'Ireland, empire and union, 1690-1801', in Kenny (ed.), Ireland and the British Empire, pp. 61-89 at pp. 82-88.

39 Hansard, xxix (1835), pp. 1103-1104; xxxii (1836), p. 25; xlvi (1839), p. 910. 
and in 1855 he spoke in opposition to attempts to re-open inquiries into the dethronement of the Rajah of Satara, which had taken place in $1839 .{ }^{40}$

These later speeches are noteworthy on two levels. Firstly, they are strikingly belligerent in tone. In place of the liberal-humanitarian rhetoric he had employed in 1834, which presented the empire as an enlightened and enabling enterprise which could 'liberate the Hindoo' and 'strike off the fetters of the African', Emerson Tennent now mobilised an altogether more muscular and authoritarian form of rhetoric. Defending British actions in Sind, for instance, he argued that annexation was the natural result of 'the dishonest and dishonourable conduct' of the Ameers of Sind. In short, the Ameers had behaved treacherously - that is, in opposition to British interests - and they had received a 'sound punishment' for their trouble. ${ }^{41}$ In justifying the dethronement of the Rajah of Satara he struck a similar chord. Reasoning that Satara was 'no ancient dynasty' and that the Rajah ruled 'by us under a treaty conformable to our interests', he concluded that the Rajah had been justly deposed, 'on the grounds of a treasonable conspiracy to incite the western States of India to hostility against the British, and likewise of attempting to corrupt the fidelity of the native sepoys in the British service. ${ }^{42}$ Secondly, these speeches are characterised by Emerson Tennent's increased selfconfidence, and by his representation of himself as an authority on colonial matters. Discussing the repatriation of the gates of Somnath, he refuted allegations that Ellenborough had invested the gates with 'undue importance' and maintained that their recollection 'has been preserved ... in the oral traditions and popular legends of the country', buttressing this, and his related argument that they should be viewed as national trophies, rather than religious baubles, by discussing the affair in tedious (though informed) detail, reflecting on Indian history and referring to the works of British administrator-scholars such as Sir Alexander Burnes and Sir John Malcolm. ${ }^{43}$ Here, Emerson Tennent was not merely making an argument: he was demonstrating his own expertise and familiarity with orientalist scholarly discourse. Similarly, reflecting on the treatment of the Ameers of Sind, he challenged the House of Commons' competence to adjudicate on a subject so interwoven with minute and

40 Hansard, lxvii (1843), pp. 598-612; 1xxii (1844), pp. 402-16; 1xxxii (1845), pp. 90917. For the Afghan war, the gates of Somnath and the annexation of Sind see Brendon, Decline and fall, pp. 113-16; Romila Thapar, Somanatha: the many voices of a history (London, 2005), pp. 163-92; and J. Y. Wong, 'British annexation of Sind in 1843: an economic perspective', Modern Asian Studies, xxxi (1997), pp. 225-44.

41 Hansard, lxxii (1844), pp. 405, 406, 409.

42 Hansard, lxxxii (1845), pp. 910-11.

43 Hansard, lxvii (1843), pp. 598-99, 601; ODNB, viii, pp. 901-02; xxxvi, pp. 292-95. 


\section{4}

Jonathan Jeffrey Wright

contradictory details', before himself proceeding to discuss the question at length, implicitly claiming authority and expertise as he did so. ${ }^{44}$

In accounting for the changed register of Emerson Tennent's imperial rhetoric, it is tempting to foreground the events of the First Afghan War, and to suggest that these speeches illustrate the ways in which colonial traumas impacted on the metropolitan consciousness. Indeed, a comparison might be made with the Indian Mutiny and the Morant Bay Rebellion, which precipitated a hardening of metropolitan racial thought later in the century. ${ }^{45}$ From the metropolitan perspective the Afghan war was, certainly, disturbing: a well-equipped British force had been routed, leading Blackwood's Magazine to claim that the Afghans had inflicted an 'almost irreparable injury on the British nation'. ${ }^{46}$ However, while Emerson Tennent did invoke the Afghan defeat when defending the annexation of Sind, arguing that strong actions were needed to counteract 'pernicious and injurious' impressions of British 'weakness and pusillanimity', his private correspondence reveals a more nuanced picture. ${ }^{47}$ 'You of course share in the horror at this Afghan butchery', he noted, in a letter penned in March 1842, '\& yet one cannot but feel something like sympathy with the bravery of these [Mohammedans], if it had not been tarnished by the national vice of all orientals, treachery \& barbarity. 48

While scarcely a defence of the Afghans, these ambivalent reflections hint at a more considered response to the Afghan trauma, and suggest that Emerson Tennent's parliamentary rhetoric was not quite as it seemed. But if not simply a response to the events in Afghanistan, how should these speeches be read? Bearing in mind The Economist's reflections on his chameleon-like character, a more persuasive interpretation is that Emerson Tennent was jockeying for position. By the 1840s the Board of Control for India was well established as a 'training ground for Indian administrators' and Emerson Tennent was acutely aware that it could serve as a stepping-stone to greater things: 'my new position here has opened up a field for me such as I little anticipated three months ago', he observed bullishly, in October 1841. 'I see a glorious career before me. ${ }^{49}$ In this light, Emerson Tennent's belligerent rhetoric and, in particular, his representation

\footnotetext{
44 Hansard, lxxii (1844), pp. 402-03.

45 Hall, Civilising subjects, p. 12.

46 Brendon, Decline and fall, p. 115.

47 Hansard, lxxii (1844), p. 409.

48 JET to Robert James Tennent, 14 March 1842 (PRONI, Tennent papers D/1748/G/ $661 / 172 \mathrm{~A}-\mathrm{C})$.

49 William Foster, 'The India Board (1784-1858)', Transactions of the Royal Historical Society, third series, xi (1917), pp. 61-85 at p. 65; JET to Robert James Tennent, 22 Oct. 1841 (PRONI, Tennent papers, D/1748/G/661/168A-C).
} 
of himself as a colonial authority takes on the appearance of a career-building strategy. Unwilling to merely hope for promotion, he sought to secure it by demonstrating his imperial knowledge and articulating robust support for aggressive policies in the east. Chameleon-like, he changed his colours in a bid to establish himself as a suitable candidate for high colonial office.

\section{Experiencing empire}

So much for the means Emerson Tennent employed to secure a colonial posting, what of his experiences once he was successful? As noted, his tenure in Ceylon was a troubled one, during which he faced opposition from the so-called 'family compact', a close-knit network of civil servants, revolving around the colony's treasurer, F. J. Templar. Having wished to see the position of colonial secretary go to one of their own, the agent for the western province, Philip Wodehouse, this group's opposition to Emerson Tennent arose, in part, from jealousy. ${ }^{50}$ However, this jealousy was aggravated by the ambition Emerson Tennent displayed upon his arrival in the colony, and by his related desire to shake the status quo.

Taken from the Dutch in 1796, Ceylon had been governed by Britain for nearly fifty years by the time Emerson Tennent was appointed to the position of colonial secretary. ${ }^{51}$ Throughout the 1810 s and '20s, the colony had been administered efficiently, a state of affairs which owed much to the efforts of General Sir Thomas Maitland, governor between 1805 and 1811, who had comprehensively reformed the civil service, restructuring pay scales, abolishing unnecessary positions and encouraging staff to undertake circuits of the provinces they administered and familiarise themselves with the native languages. ${ }^{52} \mathrm{In}$ 1833, however, the Colonial Office accepted a range of cost-cutting reforms proposed in a short-sighted, utilitarian-influenced report penned by Sir William Colebrooke and this, coupled with the involvement of large numbers of civil servants in coffee planting, brought about a period of pronounced administrative malaise. In a context in which government officials were characterised by a 'disinclination to perform more than the minimum of official duties', Emerson Tennent, an ambitious metropolitan, anxious to make a name for himself and

50 De Silva, 'Sir James Emerson Tennent', pp. 15-16.

51 Initially administered from Madras, Ceylon was jointly ruled by the crown and the East India Company between 1798 and 1802, following which it was established as a crown colony. See, for an overview of the establishment of British power in Ceylon, and an account of the earlier Dutch and Portuguese periods, K. M. de Silva, A history of Sri Lanka (London, 1981), pp. 113-235.

52 Mills, Ceylon under British rule, pp. 41-58, especially pp. 50, 57 and 58. 
secure further promotion, inevitably appeared out of step. ${ }^{53}$ Privately mocking the 'superannuated veterans' who had, from 'sheer downright neglect', failed to capitalise on the potential of Ceylon, he viewed it as his responsibility to 're-construct' the colony and behaved accordingly. ${ }^{54}$ Familiarising himself with the colony's topography and conditions, he travelled widely, reputedly passing through districts which had not been visited by a government official for over thirty years. In due course, he composed a report advocating wholesale fiscal reform and, were all this not sufficient to ruffle feathers, he alienated his new colleagues still further by making little secret of the fact that he wished - indeed, expected - to be promoted to the colony's governorship. ${ }^{55}$

Emerson Tennent did not, then, conduct himself in the manner of man anxious to endear himself to his new colleagues. But while he might have been tactless, as some scholars have suggested, he cannot be held solely responsible for the difficulties he faced in the colony. ${ }^{56}$ His desire to make an impact in the colony must, for instance, be set against the advice he had received from Stanley, who pointedly informed him that 'the state of the Civil Service, and of the colony generally, required the introduction of a bold and able public servant ${ }^{2}{ }^{57}$ Added to this, it is worth noting that Emerson Tennent was far from alone in facing difficulties in Ceylon. Following his appointment as governor in 1847, Torrington found the established civil servants to be 'men of narrow minds ... more ready to discover difficulties, than to solve them', and it is clear that petty jealousies and vicious gossip flourished in the colony's close-knit British community. ${ }^{58}$ Presenting evidence to the House of Commons Select Committee on Ceylon in July 1850, Emerson Tennent identified 'that disposition to slander which exists there almost universally' as one of 'the most lamentable characteristics of society' in the colony,

53 Mills, Ceyon under British rule, pp. 65-77, 178-79 (p. 178 for quote); The ColebrookeCameron papers: documents on British colonial policy in Ceylon, 1796-1833, G. C. Mendis, ed. (2 vols, London, 1956). For coffee planting see T. J. Barron, 'Science and the nineteenth-century Ceylon coffee planters', Journal of Imperial and Commonwealth History, xvi (1987), pp. 5-23. $661 / 212 \mathrm{~A}-\mathrm{B})$.

54 JET to Robert James Tennent, 11 Jan. 1847 (PRONI, Tennent papers, D/1748/G/

55 Second report from the Select Committee on Ceylon; together with the minutes of evidence, appendix, and index, H.C. 1850 (106) xii, pp 284/322-285/323, 351/389; Third report from the Select Committee on Ceylon; together with the proceedings of the committee, minutes of evidence, appendix and index, H.C. 1851 (36) viii, pp 283/307-284/308, 351/375 (henceforth, 'Third report'); James Emerson Tennent, Reports on the finance and commerce of the island of Ceylon, and correspondence relative thereto (London, 1848); Torrington to Grey, 14 Oct. 1847, in Letters on Ceylon, p. 56.

56 Doig, 'Lord Torrington's government', p. 51; de Silva, 'Sir James Emerson Tennent', p. 15.

57 Stanley to JET, 4 April 1846 (PRONI, Emerson Tennent papers, D/2922/B/34F/14).

58 Torrington to Grey, 9 July 1847, in Letters on Ceylon, p. 14. 
and his claim is reinforced both by the evidence of Philip Anstruther, his predecessor as colonial secretary, and by the experiences of Torrington. ${ }^{59}$ Anstruther branded Ceylon 'a sort of hell upon earth', so acute was the discord he experienced in the colony, and during his time as governor Torrington not only faced rumours of domestic violence, but claims that he had paid 'undue attentions' to a certain Mrs McClean. The source of this latter rumour was none other than Lady Oliphant, wife of the colony's attorney general, but in a further rumour it was maliciously attributed to Emerson Tennent's wife, Letitia, leading Emerson Tennent to rage that Ceylon was a 'damned sink of iniquity and blackguardism'. ${ }^{60}$

While it would be easy to dismiss these divisions and animosities as inconsequential, to do so would be to overlook their profoundly serious repercussions. On a purely practical level, they served to create a stressful working environment, adding to the pressures already attendant when dealing with a potentially hostile native population in a 'very trying climate. ${ }^{61}$ More broadly, the rumours and gossip circulating in Ceylon were significant insofar as they had the potential to damage reputations far beyond the bounds of the colony itself. As Kirsten McKenzie's work on colonial scandal has demonstrated, the British Empire functioned as 'a network of information'. Colonies were linked both to other colonies and to the metropolitan centre "by a vast circuit of constantly moving personnel', and 'gossip in Cape Town could soon become gossip in Sydney, Calcutta or London'. ${ }^{62}$ By the same token, gossip in Colombo could soon become gossip in the metropolitan centre. Indeed, it did: it was in a letter from his brother, who was writing from England, that Torrington learnt of the rumour that he had beaten his wife and children. ${ }^{63}$ Above all, however, the jealousies and animosities which existed in Ceylon are of significance because it was as a direct consequence of their coming to light during the investigations of the Select Committee on Ceylon that Emerson Tennent, Torrington and Wodehouse were removed from the colony.

Relations between the three were, to say the least, complicated. According to K. M. de Silva's reading of events, when appointed as governor Torrington had

59 'Third report', p. 871/895.

60 JET to Robert James Tennent, 10 May 1849 (PRONI, Tennent papers D/1748/G/ 661/225A-E); 'Third report', p. 760/784; Torrington to Grey, 10 May 1849, in Letters on Ceylon, p. 146.

61 It is by no means insignificant that both Torrington and Emerson Tennent suffered health problems while resident in Ceylon. Torrington to Grey, 9 April 1848, 9 June 1848, 14 Sept. 1848 and 10 Feb. 1849, in Letters on Ceylon, pp. 77, 86-88, 106, 138; B. H. Farmer, Pioneer peasant colonization in Ceylon: a study in Asian agrarian problems (Oxford, 1957), pp. 21-28.

62 Kirsten McKenzie, Scandal in the colonies: Sydney and Cape Town, 1820-1850 (Melbourne, 2004), p. 7.

63 Torrington to Grey, 10 May 1849, in Letters on Ceylon, p. 146. 
mistrusted Tennent and had, instead, gravitated towards Wodehouse, albeit after an initial period in which he had been hostile towards him. ${ }^{64}$ In part, this is true. But while Torrington noted, at an early date, that he was unwilling to 'put entire confidence' in Emerson Tennent, he also conceded that his Irish subordinate had 'shown readiness to assist' and accepted that he had been unfairly treated by the family compact. Conversely, while he believed Wodehouse was 'undoubtedly clever', he characterised him as 'a very disagreeable person', a man 'inclined to be troublesome'. ${ }^{65}$ Just how troublesome Wodehouse was became clear during the course of the House of Commons' Ceylon inquiry, when he delivered evidence critical of Torrington's administration. Faced with this, Torrington's opinions hardened. Struggling to handle the pressure of the inquiry, he developed what de Silva has described as an 'almost pathological' hatred of Wodehouse, and allied himself to Tennent, whose own relations with Wodehouse were strained. As the inquiry drew to a close, this evolving three-way personality clash was thrown into sharp relief. Late in the proceedings, when it seemed as though Torrington's administration would escape without censure, Wodehouse produced a series of private letters in which Torrington reflected, in a less than flattering light, on Tennent's character. Stung, Tennent responded in kind, producing private correspondence he had received, both from Torrington and from the archdeacon of Colombo, traducing Wodehouse. ${ }^{66}$ With the circulation of this private correspondence Torrington was 'fatally damaged', but Wodehouse and Emerson Tennent fared little better. Early in December 1850, the two were informed that 'an example of such dissensions between two officers of high rank cannot fail to have a most injurious effect on the whole body of the civil servants in Ceylon' and were formally recalled from the colony. ${ }^{67}$

Conflict and division thus forms a significant theme in the story of Emerson Tennent's colonial experience. Indeed, his short-lived career as an imperial administrator illustrates the profoundly disruptive impact private disputes and personality clashes could have within the hot-house environment of a close-knit colonial community and, in so doing, affirms Nicholas Thomas' assertion that '[c]olonialism is not a unitary project but a fractured one, riddled with contradictions and exhausted as much by its own internal debates as by the resistance of the colonised. ${ }^{68}$ But to focus solely on conflict and exclusion is to

64 De Silva, "The 1848 "rebellion" in Ceylon ... part i and part ii', p. 70.

65 Torrington to Grey, 9 July 1847, in Letters on Ceylon, pp. 43-44.

66 De Silva, 'The 1848 "rebellion" in Ceylon ... part i and part ii', pp. 62, 70-73, 126-27;

de Silva 'Sir James Emerson Tennent', pp. 19-20.

67 Quoted in de Silva, 'Sir James Emerson Tennent', pp. 20-21.

68 Nicholas Thomas, Colonialism's culture: anthropology, travel and government (Cambridge 1994), p. 51. 
reveal only one aspect of a multifaceted colonial experience. Equally significant, when thinking of the Ulster experience of empire, were Emerson Tennent's activities as an imperial collector and his connections, within Ceylon, with a group of Irishmen from Belfast.

Over the course of the nineteenth century, Irishmen played a prominent role in Ceylon. Between 1860 and 1903 Ireland supplied four of the colony's governors; a succession of high-ranking Irish officers shaped the Ceylon Police; and during Emerson Tennent's sojourn in the colony it was a Co. Kilkenny man, Dr Christopher Elliott, who edited the Colombo Observer. ${ }^{69}$ As a radical, who espoused the extension of the franchise to natives and opposed the tax reforms introduced by Torrington's administration, Elliott was by no means a natural ally for Emerson Tennent, but there were other Irishmen present in the colony. Indeed, Emerson Tennent's presence seems to have encouraged a number of individuals from Belfast to seek careers in Ceylon. His private correspondence contains numerous letters requesting that he exercise his influence to secure positions for Belfast-men, and in May 1848 Torrington complained that 'people are continually arriving from the neighbourhood of Belfast and at various times have been slipped into the service'. The immediate pretext for this complaint was the arrival in the colony of two Belfast-men, a 'Mr MacCarthy' and a 'young man of the name Cairns'. This 'Mr MacCarthy' was, in fact, William Macartney, an officer in the Royal Irish Constabulary who had travelled out to take up the position of Superintendent of Police, while 'Cairns' was William Wellington Cairns. Whether or not Emerson Tennent had assisted Macartney in securing a place in the Ceylon is unknown, but he certainly assisted Cairns, advising him on the best way to prepare himself for a position in the civil service and requesting permission from Torrington to 'place him [as] a volunteer in the Cutchery'. In due course, this strategy succeeded: Cairns was formally appointed to Ceylon's civil service in 1852, and he went on to hold positions in Malacca, St Kitts, Honduras and Queensland. ${ }^{70}$

69 O'Leary, Servants of the empire, p. 52; Georgina Sinclair, 'The "Irish" policeman and the empire: influencing the policing of the British Empire-Commonwealth', Irish Historical Studies, xxxvi (2008), pp. 173-87 at p. 183; Tropical Agriculturist, xiii (1893), pp. 361-67; C. A. Bayly, Recovering liberties: Indian thought in the age of liberalism and empire (Cambridge, 2011), pp. 128-29.

70 Cairns to Robert James Tennent, 6 April 1848 (PRONI, Tennent papers D/1748/G/ 87/2A); Torrington to Grey, 9 June 1848, in Letters on Ceylon, p. 85; Jim Herlihy. Royal Irish Constabulary officers: a biographical dictionary and genealogical guide, 1816-1922 (Dublin, 2005), p. 199; R. B. Joyce, 'Cairns, Sir William Wellington (1828-1888)', Australian Dictionary of Biography, National Centre of Biography, Australian National University, http://adb.anu.edu.au/ biography/cairns-sir-william-wellington-3141/text4683, accessed 18 April 2013. 
In addition to Cairns, Emerson Tennent is known to have associated closely with two other Belfast-men in Ceylon: Dr Robert Templeton, a surgeon in the Royal Artillery who had been present in the colony since 1839; and Andrew Nicholl, the Belfast painter who took up a position as teacher of landscape painting and scientific drawing in the Colombo Academy in $1846 .{ }^{71}$ Both men had been well-known to Emerson Tennent in Belfast and it is scarcely surprising that the three gravitated towards each other in Ceylon, forming a support network of sorts. In July 1848, for instance, Emerson Tennent permitted Nicholl to accompany him on an official tour of the island, enabling him to sketch its interior. ${ }^{72}$ More significantly, Emerson Tennent is known to have used Templeton as a go-between in an unsuccessful attempt to affect a rapprochement with Philip Wodehouse and when Templeton's friend Edgar Layard fell ill Emerson Tennent took an interest in his affairs and employed him in his office. ${ }^{73}$ Thus, beyond simply highlighting the presence of Belfast-men in Ceylon, the Nicholl/Templeton/Emerson Tennent circle offers a neat example of such men interacting and forming networks based on prior acquaintance. Although informal, such networks were, as Crosbie has recently demonstrated, of signal importance both to the Irish imperial experience and, insofar as they 'enabled the operation of a vast system of dialogue and exchange', to the working of the empire. ${ }^{74}$

Leaving aside its significance as a node in the 'software of empire', the Nicholl/Templeton/Emerson Tennent circle is rendered still more interesting because of its members' desire to amass knowledge and 'know' Ceylon - a desire enacted in the practice of collecting. ${ }^{75}$ All three collected, although in different ways. Nicholl, for example, collected a pictorial record of Ceylon, compiling a portfolio of sketches and watercolours on which he was later to draw when providing illustrations for Emerson Tennent's writings on the colony. ${ }^{76}$

71 Helena C. G. Chesney and Robert Nash, 'Robert Templeton, 1802-92', in John Wilson Foster and Helena C. G. Chesney (eds), Nature in Ireland: a scientific and cultural history (Dublin, 1997), pp. 349-54; Martyn Anglesea, 'Andrew Nicholl and his patrons in Ireland and Ceylon', Studies, lxxi (1982), pp. 130-51; J. R. R. Adams, 'Andrew Nicholl', Irish Arts Review, i (1984), pp. 29-34.

72 Andrew Nicholl, 'A sketching tour of five weeks in the forests of Ceylon', Dublin University Magazine, xl (1852), pp. 527-40, 691-700.

73 'Third report', p. 826/850; Chesney and Nash, 'Robert Templeton', p. 351.

74 Crosbie, Irish imperial networks, p. 254.

75 Ibid.

76 James Emerson Tennent, Ceylon: an account of the island physical, historical and topographical, with notices of its natural history, antiquities and productions (2 vols, London, 1859), i, pp. 96, 97, 98, 343, 357, 375, 392. 
Conversely, Templeton collected in the field of entomology. Collaborating with Edgar Layard, he amassed sizeable collections of butterflies, moths, beetles and shells, and identified a number of hitherto unknown species. ${ }^{77}$ Of the three, however, it was Emerson Tennent whose collections were the most impressive. In addition to 'collecting' extensive knowledge of Ceylonese culture, geography and antiquities during his tours of the island, he gathered shells and entomological specimens, acquired ethnographic artefacts and purchased numerous examples of native arts and crafts. ${ }^{78}$ Writing early in 1847, he described Ceylon as 'a wonderful place for Natural History', and by that point he could already boast 'a collection of shells of about 1,000 specimens', 'a collection of insects that fills upwards of twenty cases' and 'some splendid pieces of arms, in the manufacture of which the Cingalese used to excel'. ${ }^{79}$

In itself, there was nothing particularly remarkable about this activity. Earlier governors of Ceylon, such as Sir Robert Brownrigg and Sir Edward Barnes had acquired extensive collections of objets d'art and native carving, and collecting has long been recognised as a corollary of imperial expansion. ${ }^{80}$ Bernard Cohn, for instance, has observed that 'most of the significant collections of texts, paintings, sculptures, artifacts, and even botanical and zoological specimens which were later to show up in museums in Great Britain and India were the result of individual and personal efforts', while Maya Jasanoff has recently argued for the utility of collecting as an interpretive paradigm for the expansion of empire more broadly, noting that the British Empire might itself be viewed as a kind of collection: pieced together and gaining definition over time, shaped by a range of circumstances, accidents and intentions. ${ }^{81}$ In collecting, then, Emerson Tennent and his associates engaged in an archetypal imperial activity. However, as common as it was, at all levels of empire, the practice of collecting remains of central importance in the story of Emerson Tennent's imperial life, for it was the

77 Chesney and Nash, 'Robert Templeton', pp. 350-51.

78 [HOK Fine Art], The Langham family collections from Cottesbrooke Hall and Tempo Manor: Monday, 27th September, 2004 at 10.30am (Dublin, 2004), pp. 90-104; Robin Jones, 'An Englishman abroad: Sir James Emerson Tennent in Ceylon, 1845-50', Apollo (1 Nov. 2006), pp. 36-43 (note the misidentification of Emerson Tennent as an Englishman); Arthur Deane (ed.), The Belfast Natural History and Philosophical Society: centenary volume, 1821-1921 (Belfast, 1924), p. 167. $661 / 212 \mathrm{~A}-\mathrm{B})$.

79 JET to Robert James Tennent, 11 Jan. 1847 (PRONI, Tennent papers, D/1748/G/

80 Jones, 'An Englishman abroad', p. 41.

81 Bernard Cohn, Colonialism and its forms of knowledge: the British in India (Princeton, 1996), p. 97; Maya Jasanoff, Edge of empire: lives, culture, and conquest in the east, 1750-1850 (New York, 2005), p. 6. 
collections he amassed in the colonial context - collections of both knowledge and 'things' - that enabled him to continue his imperial career upon his return to the metropole.

\section{Bringing empire home}

While in Ceylon, Emerson Tennent had hoped to acquire first-hand expertise of colonial governance, which would enable him to contribute to later parliamentary debates regarding the empire's future. As early as 1846, in a letter which reflects his belief that colonial service could form a part of, rather than a substitute for, or an adjunct to, a longer metropolitan political career, he explained his plan to Earl Grey, who had recently been appointed to the colonial office, and who he feared might move him from Ceylon to a different colony.

In six years hence the charter of the East Indian Co. will expire \& Parliament will be called on to decide what is to be the new form of Government of that vast Empire ... I hope on my return to the House of Commons to bring some assistance; the result of my long theoretical acquaintance with Indian affairs ripened \& rendered valuable by my practical experience of all the details of govt. in a Great Indian colony ... To carry me away from Ceylon therefore would utterly defeat my hopes \& prospects of usefulness on this great question ... 82

In the end, this was not to be: although Emerson Tennent returned to the House of Commons in 1851, he remained there for less than a year, during which time he was not required to bring his 'theoretical acquaintance' and 'practical experience' of empire to bear on parliamentary discourse. Nevertheless, he was to contribute, beyond parliament, to a broader process of knowledge creation which enabled a metropolitan public to 'experience' empire.

There were, of course, many ways for the metropolitan public to encounter empire. Schooling, religion and the consumption of imperial goods could all facilitate colonial encounters, but one of the most significant ways empire was experienced was through the reading of colonial literature. ${ }^{83} \mathrm{~A}$ broad ranging genre, if genre it can be called, colonial literature encompassed missionary writing,

82 JET to Grey, 10 Sept. 1846 (Durham University Archive, Grey papers, GRE/

83 Hall and Rose, 'Introduction', pp. 28-29. 
scientific studies, travel narratives and combinations of all three forms, such as David Livingstone's hugely successful Missionary travels and researches in South Africa (1857). ${ }^{84}$ Through such writing, the learned and leisured came to know - or, at any rate, to think they knew - their empire, and it is within this wide-ranging body of literature that we may locate the four books in which Emerson Tennent presented the knowledge he had collected while employed in imperial service - Christianity in Ceylon (1850), Ceylon: an account of the island, physical, historical and topographical (1859), Sketches of the natural history of Ceylon (1861) and The wild elephant and the method of capturing and taming it in Ceylon (1867).

Of the four, it was the two-volume Ceylon which was the most significant. Many years in gestation, Emerson Tennent had begun work on the book at least as early as January 1847, in which year he reported that he was busy on a 'work on Ceylon, of which nothing is known in Europe'. ${ }^{85}$ This was not, strictly speaking, true: leaving aside accounts produced elsewhere in Europe, the first English work on Ceylon, Robert Knox's Historical relation of Ceylon, was published with the imprimatur of the Royal Society in $1681 .^{86}$ Moreover, in the half-century following its establishment as a British colony, missionaries, soldiers and administrators had produced a series of works on Ceylon, both in the form of popular narratives and specialised studies of its languages and antiquities. ${ }^{87} \mathrm{To}$ name just a few, these included, Robert Percival's An account of the island of Ceylon (1803), James Cordiner's A description of Ceylon (1807), John Davy's An account of the interior of Ceylon and of its inhabitants, with travels in that Island (1821),

84 Anna Johnson, Missionary writing and empire, 1800-1860 (Cambridge, 2003); Justin Livingstone, 'Missionary Travels, missionary travails: David Livingstone and the Victorian publishing industry', in Sarah Worden (ed.), David Livingstone: man, myth and legacy (Edinburgh, 2012), pp. 33-51 at pp. 34-35.

85 JET to Robert James Tennent, 11 Jan. 1847 (PRONI, Tennent papers D/1748/G/ $661 / / 212 \mathrm{~A}-\mathrm{B})$

86 C. R. Boxer, 'Ceylon through Puritan eyes: Robert Knox in the kingdom of Kandy, 1660-1679', History Today, iv (1954), pp. 660-67; Anna Winterbottom, 'Producing and using the Historical Relation of Ceylon: Robert Knox, the East India Company and the Royal Society', British Journal for the History of Science, xlii (2009), pp. 515-38. For earlier European accounts see C. R. Boxer, 'Captain João Ribeiro and his history of Ceylon, 1622-1693, Journal of the Royal Asiatic Society, new series, lxxxvii (1955), pp. 1-12.

87 For early British attempts to 'know' Ceylon see Sujit Sivasundaram's 'Buddhist kingship, British archaeology and historical narratives in Sri Lanka, c.1750-1850', Past E Present, 197 (2007), pp. 111-142 and 'Islanded: natural history in the British colonization of Ceylon', in David N. Livingstone and Charles W. J. Withers (eds), Geographies of nineteenth-century science (Chicago, 2011), pp. 123-148. See also de Silva, 'Sir James Emerson Tennent', pp. 23-24. 
William Knighton's Forest life in Ceylon (1854) and Samuel Baker's Eight years wanderings in Ceylon (1855). ${ }^{88}$

Emerson Tennent was not, then, the first to publish on Ceylon, but in an increasingly crowded field his book soon emerged as the book on Ceylon. Reflecting an orientalist desire to 'divide, deploy, schematize, tabulate, index, and record everything in sight', Ceylon offered a fuller and more broad-ranging account of the colony than had previously been available. ${ }^{89}$ Synthesizing existing scholarship, and presenting vast amounts of new research, the book addressed Ceylon's geography, natural history, geology, climate and fauna, in addition to its antiquities, literature and history, and was quickly judged a classic. As early as December 1859, Chamber's Journal predicted that it would 'doubtless henceforth enjoy a place in every respectable library, in companionship with the celebrated work of Bishop Heber on India.$^{90}$ By the following May it had run into a fifth edition, and some fifteen years later it remained unsurpassed: when passing through Ceylon while en route to Australia in 1875, Anthony Trollope read the book and characterised it, in the travel letters he published in the Liverpool Mercury, as 'the most learned book ever written on any colony. .1

To foreground Ceylon's success is not to suggest that it was a book without flaws. Learned it might have been, but it was comprehensive to a fault and Trollope was rather less complimentary in private. 'I have read the first volume of Tennant's [sic] Ceylon,' he noted, in a letter to his wife. 'Nothing longer or duller ever was written. ${ }^{92}$ Others made similar observations. In February 1860, a waggish contributor to the Dublin University Magazine quipped that '[1]ife is short and Tennent is long', and the writer and translator Edward Fitzgerald confessed that he could 'hardly manage' the book, it being 'a very Dry Catalogue Raisonnée of the Place'. ${ }^{93}$ Yet, in an age of ponderous books and earnest readers

88 The writings and public careers of Emerson Tennent and Samuel Baker White are compared in James H. Warren, 'Contesting colonial masculinity/constituting imperial authority: Ceylon in mid-nineteenth-century British public debate', Nerw Zealand Journal of Asian Studies, vi (2004), pp. 39-62.

89 Edward W. Said, Orientalism, 25th anniversary ed. (New York, 2003), p. 86.

90 Chambers's Journal, fifth series, 311 (1859), p. 395.

91 The Critic, xx (1860), p. 153; The Athenaeum, 1698 (1860), p. 649; Anthony Trollope, The tireless traveller: twenty letters to the Liverpool Mercury, 1875, (ed.) Bradford Allen Booth (Berkeley, 1941), p. 60; K. M. de Silva, 'Ceylon' in Robin W. Winks (ed.), The Oxford history of the British Empire: volume v, historiography (Oxford, 1999), pp. 243-252 at p. 244.

92 Anthony Trollope to Rose Trollope, 17 March 1875, in The letters of Anthony Trollope, ed. N. John Hall (2 vols, Stanford, 1983), ii, p. 654.

93 Dublin University Magazine, lv (1860), p. 235; Fitzgerald to W. F. Pollock, 23 Feb. 1860, in The letters of Edward Fitzgerald, vol. II: 1851-1866, Alfred McKinley Terhune and Annabelle Burdick Terhune, ed. (Princeton, 1980), p. 352. 
Ceylon's encyclopaedic character was no bar to success. Fitzgerald tellingly conceded that it was the sort of book that 'ought to be admired', and admired it was. $^{94}$ It not only sold in the thousands, but some sought to emulate its exhaustive quality in their own work. 'I do not intend to write a narrative of my travels except as part of a work on Africa generally', the novelist and travel writer William Winwood Reade informed Charles Darwin, when researching his African sketch book (1873). 'I am ambitious of doing for negro travel what Tennent has done for Ceylon; \& I intend to read every book of travels relating to W[est] \& Central Africa \& East Africa. ${ }^{, 95}$

What, precisely, Emerson Tennent had 'done for Ceylon' was produce an account which drew together all existing knowledge of the colony, an account which was widely accepted as definitive, and against which all subsequent works would be judged, often to their detriment. ${ }^{96}$ As such, it was an account which shaped the way in which Ceylon was viewed and experienced. Whatever the character of his private thoughts, it was by no means insignificant that Trollope read the book while in Ceylon. His experience of Ceylon, and in particular his response to its antiquities, were in part mediated by Emerson Tennent's written account, and he was not alone in turning to Ceylon to make sense of the sights he encountered in the colony. ${ }^{97}$ The aristocratic travel writer Annie Brassey likewise turned to Emerson Tennent during a visit to Ceylon, and her comments reflect the way in which her experience of the colony was informed by his depiction of it: 'I have not been able to keep my mind from running incessantly on Sir Emerson Tennent's delightful book on Ceylon, which describes places we have not ourselves visited, but which I wanted very much to see, and I have been so interested in reading about them that I cannot help thinking other people will share my feeling. ${ }^{98}$ While experiencing the 'real' Ceylon, Brassey was reflecting on an imagined Ceylon, shaped, it would appear, by Emerson Tennent's written account.

94 Fitzgerald to Stephen Spring Rice, 2 March 1860, in The letters of Edward Fitzgerald, Terhune and Terhune, ed. p. 355.

95 Reade to Darwin, 6 Nov. 1870, in Frederick Burkhardt et al (eds.) The correspondence of Charles Darwin, vol. 18, 1870 (Cambridge, 2010), p. 279.

96 When a former officer of the Ceylon Rifles published his account of the island in 1876, The Athenaeum observed that it invited comparison with 'the well-known work of Sir James Emerson Tennent', and that this comparison proved 'disastrous' to the more recent work. The Athenaeum, 2522 (1876), p. 293.

97 Trollope, The tireless traveller, pp. 49, 51-52, 60.

98 Quoted in Nancy Micklewright, A Victorian traveller in the Middle East: the photography and travel writing of Annie Lady Brassey (Aldershot, 2003), p. 32. 


\section{6}

\section{Jonathan Jeffrey Wright}

As a writer, Emerson Tennent thus made a significant contribution to the process whereby Ceylon was 'known' and 'experienced'. However, he also contributed to the construction of imperial knowledge at a local level, and it is here that his collection of 'things' (that is, artefacts and scientific specimens), as opposed to his collection of knowledge, becomes significant. Although much of the material he collected in Ceylon was destined for his country residence in Tempo, Co. Fermanagh, Emerson Tennent also donated substantial collections to the BNHPS. ${ }^{99}$ Established in 1821, 'for the purpose of cultivating Natural History, and diffusing a taste for that science', the BNHPS was, for much of the nineteenth century, Belfast's most significant scientific body and, in 1831, it opened a museum, 'the first institution of the kind ever erected in Ireland by voluntary subscriptions. ${ }^{100}$ As a young man, Emerson Tennent had been numbered among the society's earliest members, and he retained a connection to it throughout the 1830s and '40s, a connection illustrated by the episode reported by The Economist in 1844 - his donation of a live chameleon, which he had caught on Mount Calvary. ${ }^{101}$ This was, however, only one of a series of contributions Emerson Tennent made to the collections of the BNHPS. The following year, while travelling to Ceylon, he toured the Nile Valley and, having secured permission from the Egyptian ruler, Muhammad Ali, acquired two mummies from Thebes and a fragment of statue from the Grand Temple of Karnak. ${ }^{102}$ These items were, in due course, donated to the BNHPS, as were a series of specimens of 'great interest and value' which he collected in Ceylon, including 'an extensive and most attractive' collection of entomological specimens, 'a large and beautiful collection of shells', 'specimens of the Ant Lion' and ethnographic objects, including three ornate masks, worn during so-called 'Devil dances.' ${ }^{103}$

99 [HOK Fine Art], The Langham family collections, pp. 90-104.

100 Initially the Belfast Natural History Society, the name was changed to the Belfast Natural History and Philosophical Society in 1842. Belfast Almanack (1830), p. 50; James Adair Pilson, History of the rise and progress of Belfast, and annals of the County Antrim, from the earliest period till the present time (1846), pp. 162-63; Deane (ed.), Centenary volume, pp. 2, 5-8, 12.

101 Minute book of the Belfast Natural History Society, 1821-1830 (PRONI, BNHPS papers, D/3263/AB/1), entry for 19 July 1821.

102 [Northern Whig], Special meeting of the Natural History and Philosophical Society of Belfast, held in the music-hall, on Wednesday, the 23d of October, 1850, relative to two mummies transmitted from Thebes, by Sir James Emerson Tennent, and unrolled in the museum, on the 17 and 18 of the above month (Belfast, 1850), pp. 26-28.

103 Reports of the council of the Belfast Natural History Society/Belfast Natural History and Philosophical Society (1849), p. 3; (1853), p. 4; (1854), p. 3; (1857), p. 4; [BNHPS], Report of a meeting of which took place on 1 March 1854 (Belfast, 1854), p. 1; Deane (ed.), Centenary volume, pp. 18-19, 46, 167. 
The significance of these donations is twofold. On the one hand, they offer a neat illustration of the process of reverse or inverted ornamentalism. As employed by Cannadine, the concept of ornamentalism concerns the display of British power in the empire. ${ }^{104}$ By contrast, inverted ornamentalism may be said to concern the ways in which colonial actors projected themselves in the context of the metropole. For Emerson Tennent, collecting and donating served as a means by which he could project and maintain a reputation, in the Belfast context, as an imperial figure. Indeed, while his experiences as an imperial administrator in Ceylon were short-lived and disappointing, it might be suggested that, alongside writing, collecting and donating offered him a more positive imperial identity: Emerson Tennent the writer, who donated specimens and artefacts to the BNHPS, was not an imperial failure, but an imperial success.

Added to this, Emerson Tennent's donations are significant in a broader sense insofar as they highlight the role the BNHPS played in providing a point of contact with the empire. Had Emerson Tennent's donations been unique this point would be a minor one. However, as its records reveal, the BNHPS had, almost from the start of its existence, cultivated links with Irish-men - and, in particular, Belfast-men - abroad in a bid to augment its collections. In May 1828, for instance, a circular letter was drawn up '[f]or the purpose of directing to this society the attention of our countrymen abroad'. This not only requested that recipients co-operate with the society's aims by 'sending such specimens connected with our pursuits, as occur in their respective places of abode', but gave detailed instructions as to how specimens should be preserved and packed. ${ }^{105}$ Five years later, the museum's curators impressed upon members 'the propriety of making application to all persons residing abroad, and connected with Belfast', and in the following decades, specimens and artefacts, both scientific and ethnographic, were donated by merchants, soldiers and administrators, and a collection was created which was global in scope. ${ }^{106}$ To name just a few of the many individuals who donated material, the Belfast-born naval surgeon Charles Telfair sent seeds and zoological specimens from Mauritius in 1830; the traveller Gordon Augustus Thomson donated a collection of objects including weaponry and handicrafts from Africa in 1834, and later gave a larger collection of ethnographic objects gathered in Australia, the Pacific Islands and the

104 Cannadine, Ornamentalism, passim.

105 Minute book of the Belfast Natural History Society, 1821-1830 (PRONI, BNHPS papers, D/3263/AB/1), entry for 24 May 1828.

106 Report of the council of the Belfast Natural History Society (1833), p. 2. 
Americas; and a Lieutenant James Hamilton presented an Indian collection, including idols, ornaments and clothing, in $1836 .{ }^{107}$

Such objects, exhibited in the BNHPS's museum, provided an opportunity to encounter cultural 'others' and experience empire, albeit at a remove, and it was not just the staunchly middle-class membership of the BNHPS that availed of this opportunity. Beginning in 1845, the BNHPS introduced a scheme whereby Belfast's working classes would be admitted to the museum at a reduced rate on Easter Monday. This event quickly proved popular. Attendance figures rose from around 1,000 in 1845 to an average of nearly 5,000 during the period 1849-53, and by 1873 the continued popularity of the Easter Monday opening led the BNHPS council to boast that the holiday 'seems now inseparably connected in the minds of the rising generation with a visit to the Belfast Museum'. ${ }^{108}$ For the thousands who visited, the BNHPS's museum offered a window on a wider world and facilitated imperial encounters in the heart of Belfast. Ostensibly a local scientific society, the BNHPS was, in fact, an imperially networked society whose members participated consciously in a process of collecting and donating whereby the empire was brought home and placed on display. ${ }^{109}$ If it was, as Jasanoff has written, 'through objects that millions of British women and men literally "saw their empire", it was thanks to the BNHPS, and to individuals such as Emerson Tennent, that the population of Belfast shared the view. ${ }^{110}$

\section{Conclusion}

While he spent only five years in the empire, Sir James Emerson Tennent can, in conclusion, be said to have lived a varied and multifaceted colonial life. A chameleon-like character, he assumes a range of different guises - ambitious and imperially-conscious parliamentarian, marginalised colonial administrator, Ulsterman in empire, imperial collector and writer on Ceylon - depending on the context in which he is viewed, and his life-story sheds light on the complex

107 Deane (ed.), Centenary volume, pp. 165-67; Winifred Glover, 'In the wake of Captain Cooke: the travels of Gordon Augustus Thomson (1799-1886), principal donor of ethnographic objects to the Ulster Museum, Belfast', Familia, ii (1993), pp. 46-61; Marc Serge Rivière, 'From Belfast to Mauritius: Charles Telfair (1778-1833), naturalist and a product of the Irish Enlightenment', Eighteenth-Century Ireland, xxi (2006), pp. 125-44.

108 Reports of the council of the Belfast Natural History Society/Belfast Natural History and Philosophical Society (1849), p. 3; (1853), p. 5; (1873), p. 3.

109 Ruth Margaret Bowman Bayles, 'Science in its local context: the Belfast Natural History and Philosophical Society' (PhD thesis, Queen's University Belfast, 2005).

110 Maya Jasanoff, 'Collectors of empire: objects, conquests and imperial self-fashioning', Past Eं Present, 184 (2004), pp. 109-135 at p. 112. 
and many-sided nature of imperial lives. Taken as a whole, the trajectory of his career, and his desire to secure colonial high office, before returning to parliament, highlights the 'integratedness' of the colonial and the metropolitan. As such, his story reinforces the thrust of much of the so-called 'new' imperial history. But what is especially significant is Emerson Tennent's apparent awareness of, and desire to exploit, the connections that existed between the metropole and its colonies. The empire was not, for Emerson Tennent, a place apart, but a space in which ambition could be pursued and a border-crossing career could be played out. Of course, as he experienced it in Ceylon, empire's reality proved somewhat disappointing and his story is also one of frustrated ambition and colonial division. It is a story which illustrates imperialism's contradictions and internal divisions. Yet as difficult as his time in Ceylon was, it also provided Emerson Tennent with an opportunity to collect resources - both in terms of knowledge and things - which he successfully exploited upon his return to the metropole. Once back in Britain, the Belfast chameleon changed again, establishing himself as an acknowledged expert on Ceylon. Through his writings and donations of scientific and ethnographic materials to the BNHPS, Emerson Tennent continued to pursue an imperial career of sorts, placing the empire on display, both literally and textually, and facilitating imperial encounters. Thus his story is also a story which concerns the construction and reception of colonial knowledge and one which, more particularly, highlights the role of the BNHPS in linking mid-nineteenth-century Belfast, culturally and intellectually, to empire. To draw an overarching conclusion from all of this is by no means straightforward, and so much the better - the imperial experience was a complex one, both for the colonised and the coloniser, and should be treated as such. At the very least, however, the imperial life of Sir James Emerson Tennent suggests that there was rather more to the Ulster experience of empire than a flurry of imperial flagwaving triggered by the spectre of Home Rule. 
Copyright of Britain \& the World is the property of Edinburgh University Press and its content may not be copied or emailed to multiple sites or posted to a listserv without the copyright holder's express written permission. However, users may print, download, or email articles for individual use. 